\title{
To Maximize Heating Performance of Solar Parabolic Trough Collector by Geometrical Variation Using CFD Analysis
}

\author{
Kripa Shankar Pathak \\ M.Tech Scholar \\ Department of Mechanical Engineering \\ IES College of Technology \\ Bhopal, India \\ kripadon.pathak7@gmail.com
}

\author{
Ravindra Mohan \\ Assistant Professor \\ Department of Mechanical Engineering \\ IES College of Technology \\ Bhopal, India \\ ravindra.mohan09@gmail.com
}

\begin{abstract}
The potential of renewable energy should be investigated. Renewable energy is the energy from natural and unnatural available forms including wind, biomass, solar, and waste heat energy generated through various human activities. Solar energy is an available and clean form of renewable energy used as an alternative to fossil fuel in generating energy. However, the maximum extraction of thermal energy from the sun is most challenging. This study focuses on energy generation using the parabolic trough collector (PTC). This review contains geometrical analysis including the thermal approach of the PTC model, heat transfer, and method of enhancing thermal efficiency on the PTC receiver. So to identify the performance analysis, thermal efficiency, and applications of the solar-powered PTC and the history of PTC evolution. The PTC applications include desalination process, air heating system, power plants, refrigeration, and industrial heating purposes.
\end{abstract}

Keyword - parabolic trough collector, heat system.

\section{INTRODUCTION}

Solar energy is a kind of unconventional energy source that uses solar radiation to generate energy or for other domestic and industrial purposes. It is a source of renewable energy, also called green energy. Because the rapid development of renewable energy technologies has a complete impact on the environment and on society. Some renewable energy sources produce very low $\mathrm{CO}_{2}$ emissions and also contribute to reducing global warming. It also reduces air pollution and contributes to social and economic development by creating jobs in rural and urban areas.

According to the "WORLD ENERGY COUNCIL" Since 1970, there has been a rapid growth in demand for fossil fuels. The future will be different. There are destructive tendencies that will create a fundamentally new world for the energy economy, characterized by a lower population growth, new radical technologies, great environmental problems and a shift in economic and geopolitical power. These basic drivers will change the energy industry. This is called an insecure journey into a new world of energy. The purpose of a solar energy collector is to gather the radiant energy falling on its surface and then transfer this energy to fluid which is in contact with the collecting surface. These are classified as:

Concentrating

Non-concentrating

The basic difference between these is that of the absorber area. In a non-concentrating collector absorber area is nearly same as that the recipient area but on the other hand the energy falling on a large recipient area is focused on a small absorber area.

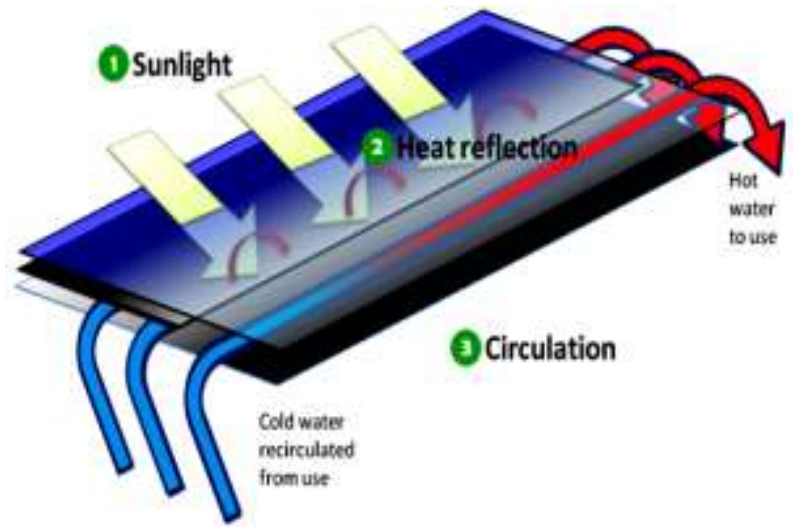


Figure 1 Flat plate collector

Solar energy has wide variety of applications which are classified as follows:

Urban planning and architecture

Horticulture and agriculture

Steam Cooking/ Heating

Process Heating

- Cooling and refrigeration

- Desalination of water

- Power/ Electricity generation

Solar energy is a fantabulous source for meeting our electricity requirements. Solar PV (photovoltaic) possesses the ability of direct conversion of incoming solar radiations into electricity. This energy can tapped using PV cells and can be stored using battery which can be further used as per the demands. These can be used for such purposes:

- Village electrification

- Water pumping

- Street lighting

- Domestic lighting

- Mini grid

\section{LITERATURE REVIEW}

Evangelos Bellos, et al. [1] in this paper is to investigate the optimum number and location of the internal fins in the absorber of a parabolic trough collector. The examined fins have $10 \mathrm{~mm}$ length and $2 \mathrm{~mm}$ thickness, while their shape is rectangular. Various numbers of fins are investigated in various locations inside the absorber and in every case; the collector's performance is investigated by taking into account the increase of the Nusselt number and of the friction factor. According to the final results, the internal fins have to be placed in the lower part of the absorber where the higher amount of the solar heat flux is concentrated. A multi-objective procedure proved that the absorber with three fins in the lower part is the optimum case with $0.51 \%$ thermal efficiency enhancement.

Hamed Hoseinzadeh, et al. [2]This research is aimed at geometric analysis of parabolic trough solar collector (PTC) in different sizes of the main components of the system. The rate of the Local Concentration Ratio (LCR) on the receiver tube and optical efficiency are two main features in geometric optimization of the parabolic trough solar collectors. In this work, parabolic trough solar collector was optimized for different sizes with three design variables: the receiver diameter, the collector aperture width and the rim angle. The method used in this research was the Monte Carlo Method (MCM) in MATLAB.

Salamanca S, Merchán P, Adán A \& Pérez E [3] This paper presents an original method for the analysis of the geometric and optical properties of parabolic solar trough collectors using laser scanners and image processing techniques. The aim of the paper is to propose a methodology with which to automatically analyse geometric errors in the mirror and receiver, in addition to presenting an empirical assessment of one of the most important factors that determines the entire energy efficiency of solar plants, which is optical efficiency. The definition of canonical images has allowed us to characterize a set of parameters that evaluates errors on both the surface of the parabolic reflector and regarding the orientation of the receiver.

Adriano Desideri at el. [4] In this contribution, the dynamic model of a parabolic trough line based on the ThermoCycle Modelica library is validated against steady-state and transient experimental results from the parabolic trough test loop available at the Plataforma Solar de Almería, Spain. The simulation results are in good agreement with the measurements, both in steadystate and in transient conditions. The validated model is readily usable to investigate demanding dynamics-based problems for low capacity solar power systems.

\section{OBJECTIVE}

There are following objective are to be expected from the present work

The main object of this work is to maximize the heating performance of existing absorber tube of parabolic trough collector.

To perform the computational fluid dynamics analysis on base paper design of absorber tube of parabolic trough collector.

To perform the computational fluid dynamics analysis on modified design of absorber tube of parabolic trough collector.

To compare the results and proposed best result of absorber tube of parabolic trough collector.

\section{PROPOSED METHODOLOGY}

Four model of parabolic trough collector has been developed using commercial software ANSYS. Computational fluid dynamics analyses have been performed to investigate the distribution of the temperature using Navier Stocks k- $\varepsilon$ model.

Dimensional parameters of parabolic trough collector used in present work are specified in table no. 4.1.

\begin{tabular}{|c|c|}
\hline Model dimensions & Value in $\mathbf{~ m}$ \\
\hline Length of absorber tube & 1 \\
\hline Outer diameter of absorber tube & 0.030 \\
\hline inner diameter of absorber tube & 0.0275 \\
\hline Outer diameter of glass tube & 0.0575 \\
\hline inner diameter of glass tube & 0.05 \\
\hline
\end{tabular}

Table no 1 Dimensional parameters of parabolic trough collector 1 Mathematical relations:

Mass Flow Rate:

$$
\dot{m}=\rho \mathrm{A}_{\mathrm{a}} \mathrm{V}
$$

Where,

$\rho=$ Density of working fliuid $(\mathrm{kg} / \mathrm{m} 3)$

$A_{\mathrm{a}}=$ Cross-section area of absorber tube (m2)

$\mathrm{V}=$ Velocity of air in $\operatorname{duct}(\mathrm{m} / \mathrm{s})$

The convection heat transfer between the inner tube and the working fluid is

Where:

$$
Q_{\text {conv }}=h A_{a}\left(T_{a}-T_{h o t}\right)
$$

$\mathrm{h}=$ convective coefficient between working fluid and inner surface of absorber tube

$A_{a}=$ Cross-sectional area of absorber tube

$\mathrm{T}_{\mathrm{a}}=$ ambient temperature

$\mathrm{T}_{\text {hot }}=$ Temperature of hot fluid 


$$
h=\frac{k N_{u}}{D}
$$

$\mathrm{k}=$ Thermal conductivity of the material

$\mathrm{Nu}=$ Nusselt number

$\mathrm{D}=$ Diameter of absorber tube

$$
N_{u}=\frac{\left(\frac{f}{8}\right)\left(R_{e}-1000\right) P_{r}}{1+12.7\left(\frac{f}{8}\right)^{1 / 2}\left(P_{r}^{1 / 2}-1\right)}
$$

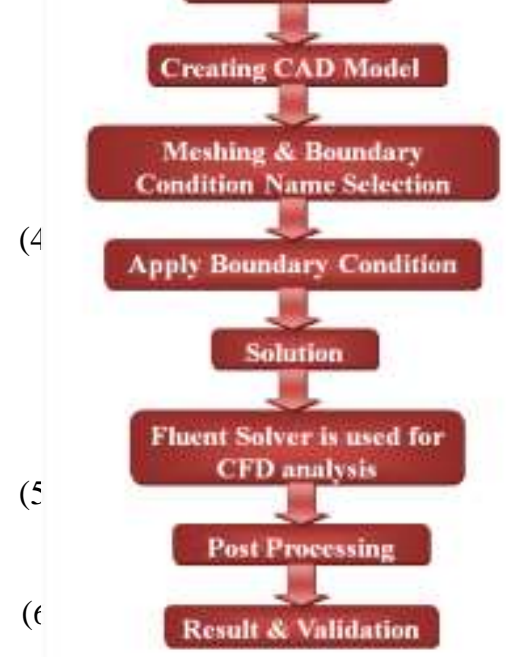

Figure 2 : Algorithm used for Computational fluid dynamics analysis The general assumptions are made for computational fluid dynamics analysis.

1. Steady state heat transfer has been considered hence heat flax and wall does not change with respect to time. 2. The flux distribution is assumed to be uniform along the surface of absorber tube.

$$
\begin{gathered}
P_{r}=\frac{\mu C_{p}}{k} \\
C_{p}=\text { Specific heat capacity in } \mathrm{W} / \mathrm{Kg} . \mathrm{K} \\
\mu=\text { Kinematic viscosity }
\end{gathered}
$$

Thermal Efficiency:

$$
\eta_{t h}=\frac{m c_{p} \Delta T}{I \times A_{s}}
$$

Where,

$\mathrm{m}=$ mass flow rate of air $(\mathrm{kg} / \mathrm{s})$

$c p=$ specific heat at constant pressure $\left(\mathrm{J} / \mathrm{kg}^{\circ} \mathrm{C}\right)$

$\Delta T=$ temperature different

$I=$ Intensity of solar radiation $\left(\mathrm{W} / \mathrm{m}^{2}\right)$

$A s=$ surface area of transparent glass $\left(\mathrm{m}^{2}\right)$

2 Computational fluid dynamics analysis:

The computational fluid dynamics analysis is carried out using Ansys fluent for absorber tube of Parabolic through collector. The input parameters have been taken from the base paper. The governing equations such as continuity equation, momentum equation, energy equations, $\mathrm{K}$ equation and $\varepsilon$ equations are used to perform this computational analysis.

\section{Algorithm used for Computational fluid dynamics analysis:}

\section{Governing Equations}

\section{Conservation of mass or continuity equation:}

The equation for conservation of mass, or continuity equation, can be written as follows:

$$
\frac{\partial \rho}{\partial t}+\nabla \cdot(\rho \vec{v})=S_{m}
$$

Where $S_{m}=$ mass added to the continuous phase or any user defined sources.

For 2D axisymmetric geometries, the continuity equation is given by

$$
\frac{\partial \rho}{\partial t}+\frac{\partial}{\partial x}\left(\rho v_{x}\right)+\frac{\partial}{\partial r}\left(\rho v_{r}\right)+\frac{\rho v_{r}}{r}=S_{m}
$$

Where $x$ is the axial coordinate, $r$ is the radial coordinate, $v_{x}$ is the axial velocity, and $v_{r}$ is the radial velocity.

\section{Momentum Conservation Equations}

Conservation of momentum in an inertial reference frame is described by

$$
\frac{\partial}{\partial t}(\rho \vec{v})+\nabla \cdot(\rho \vec{v} \vec{v})=-\nabla p+\nabla \cdot(\overline{\bar{\tau}})+\rho \vec{g}+\vec{F}
$$

Where $\mathrm{p}=$ static pressure

$\overline{\bar{\tau}}=$ stress tensor,

$\rho \vec{g}=$ gravitational body force and

$\vec{F}=$ external body forces

The stress tensor $\overline{\bar{\tau}}$ is given by

$$
\overline{\bar{\tau}}=\mu\left[\left(\nabla \vec{v}+\nabla \vec{v}^{\mathrm{T}}\right)-\frac{2}{3} \nabla \cdot \vec{v} I\right]
$$

where $\mu=$ molecular viscosity

$I=$ unit tensor 
For 2D axisymmetric geometries, the axial and radial momentum conservation equations are given by

$$
\begin{aligned}
\frac{\partial}{\partial x}\left(\rho v_{x}\right)+\frac{1}{r} \frac{\partial}{\partial x}\left(r \rho v_{x} v_{x}\right)+\frac{1}{r} \frac{\partial}{\partial r}\left(r \rho v_{r} v_{r}\right) & \\
& =-\frac{\partial p}{\partial x}+\frac{1}{r} \frac{\partial}{\partial x}\left[r \mu\left(2 \frac{\partial v_{x}}{\partial x}-\frac{2}{3}(\nabla \cdot \vec{v})\right)\right] \\
& +\frac{1}{r} \frac{\partial}{\partial r}\left[r \mu\left(\frac{\partial v_{x}}{\partial r}+\frac{\partial v_{r}}{\partial x}\right)\right]+F_{x}
\end{aligned}
$$

\section{And}

$$
\begin{aligned}
\frac{\partial}{\partial t}\left(\rho v_{r}\right)+\frac{1}{r} \frac{\partial}{\partial x}\left(r \rho v_{x} v_{r}\right)+\frac{1}{r} \frac{\partial}{\partial r}\left(r \rho v_{r} v_{r}\right) \\
=-\frac{\partial p}{\partial r}+\frac{1}{r} \frac{\partial}{\partial x}\left[r \mu\left(\frac{\partial v_{r}}{\partial x}+\frac{\partial v_{x}}{\partial r}\right)\right] \\
+\frac{1}{r} \frac{\partial}{\partial r}\left[r \mu\left(2 \frac{\partial v_{r}}{\partial r}-\frac{2}{3}(\nabla \cdot \vec{v})\right)\right]-2 \mu \frac{v_{r}}{r^{2}} \\
+\frac{2 \mu}{3 r}(\nabla \cdot \vec{v})+\rho \frac{v_{z}^{2}}{r}+F_{r}
\end{aligned}
$$

Where

$$
\nabla \cdot \vec{v}=\frac{\partial v_{x}}{\partial x}+\frac{\partial v_{r}}{\partial r}+\frac{v_{r}}{r}
$$

Where $v_{x}=$ Axial velocity

$v_{r}=$ Radial velocity

$\boldsymbol{v}_{\boldsymbol{z}}=$ swirl velocity

\section{Energy Equation:}

The energy equation for the mixture takes the following form:

$$
\begin{aligned}
\frac{\partial}{\partial t} \sum_{k=1}^{n}\left(\alpha_{k} \rho_{k} E_{k}\right)+ & \nabla \cdot \sum_{k=1}^{n}\left(\alpha_{k} \vec{v}_{k}\left(\rho_{k} E_{k}+p\right)\right) \\
& =\nabla \cdot\left(k_{e f f} \nabla T\right)+S_{E}
\end{aligned}
$$

where $k_{\text {eff }}=$ effective conductivity

$S_{E}=$ volumetric heat sources

Where

$$
E_{k}=h_{k}-\frac{p}{\rho k}+\frac{v_{k}^{2}}{2}
$$

$E_{k}=h_{k}$ for an incompressible phase and $h_{k}=$ sensible enthalpy for phase $k$

\section{$\boldsymbol{k}-\in$ model:}

The turbulence kinetic energy, $k$, and its rate of dissipation, $\in$, are obtained from the following transport equations:

$$
\begin{aligned}
\frac{\partial}{\partial t}(\rho \in)+\frac{\partial}{\partial x_{i}}(\rho \in & \left.v_{i}\right) \\
& =\frac{\partial}{\partial x_{j}}\left[\left(\mu+\frac{\mu_{t}}{\sigma_{\epsilon}}\right) \frac{\partial \in}{\partial x_{j}}\right] \\
& +C_{1 \in} \frac{\epsilon}{k}\left(G_{k}+C_{3 \in} G_{b}\right)-C_{2 \in} \rho \frac{\epsilon^{2}}{k} \\
& +S_{\epsilon}
\end{aligned}
$$

$Y_{M}$ represents the contribution of the fluctuating dilatation in compressible turbulence to the overall dissipation rate,

$C_{1 \in}, C_{2 \in}$, and $C_{3 \in}$ are constant.

$\sigma_{k}$ and $\sigma_{\epsilon}$ are turbulent Prandtl numbers for $\mathrm{k}$ and $\epsilon$,

$S_{k}$ And $S_{\in}$ are user-defined source terms.

5 Computational fluid dynamics analysis for parabßlic trough collector:

1) CAD geometry:

In the present work a two dimensional CAD model of absorber tube of parabolic trough collector is created with the help of design modular of ANSYS workbench. The inner diameter of absorber tube is taken as $27.5 \mathrm{~mm}$ with length of $1000 \mathrm{~mm} \mathrm{~A}$ two dimensional view of absorber tube is shown in figure No.

Figure 3 : CAD geometry of absorber tube of parabolic trough collector for design-1

2) Meshing: After completing the $\mathrm{CAD}$ geometry of absorber tube of parabolic trough collector is imported in ANSYS workbench for further computational fluid dynamics analysis and the next step is meshing. Meshing is a critical operation in finite element analysis in this process CAD geometry is divided into large numbers of small pieces called mesh.

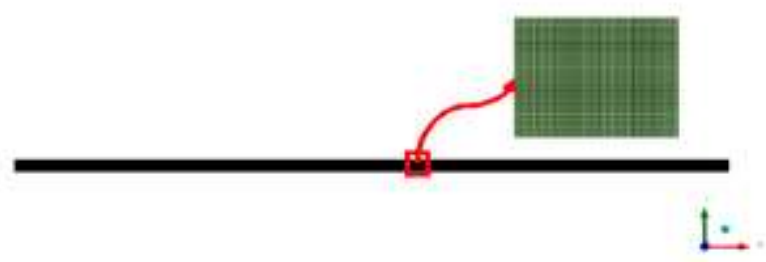

Figure 4 : Meshing: total no of nodes 71370, total no. of elements 69502

and

In these equations, $G_{k}$ represents the generation of turbulence kinetic energy due to the mean velocity gradients,

$G_{b}$ is the generation of turbulence kinetic energy due to buoyancy, 
3) Quality of meshing: The quality of the mesh plays an important role in the accuracy and stability of the calculation. In the present work the Quadrilateral elements have been generated during discretization. The quality of the cell including its orthogonal quality, aspect ratio, and skewness has an important effect on the accuracy of the solution.

6 Factor that affect the mesh quality:

- Rate of convergence: if the mesh quality is good the rate of convergence will be grater which means the correct solution can be achieved faster.

- Solution precision: A better mesh quality provides a more precise solution.

- Computational processing time required: for the highly refined mesh the computational time will be relatively large.

- Grid Independence result: Once the computations are done and the desired property of fluid does not vary with respect to different mesh elements then it represents that further change in elements doesn't vary the results this term known as Independent Grid.

7 Orthogonal mesh quality: Orthogonal quality is computed for cells using the vector from the cell centroid to each of its faces, corresponding face area vector, and the vector from the cell centroid to centroids of each of the adjacent cells. The worst cells will have an orthogonal quality closer to 0 , with the best cells closer to 1 . In the present case the minimum value is 1 and maximum value is 1 and average value is 1 , which means the mesh quality is acceptable and very good.

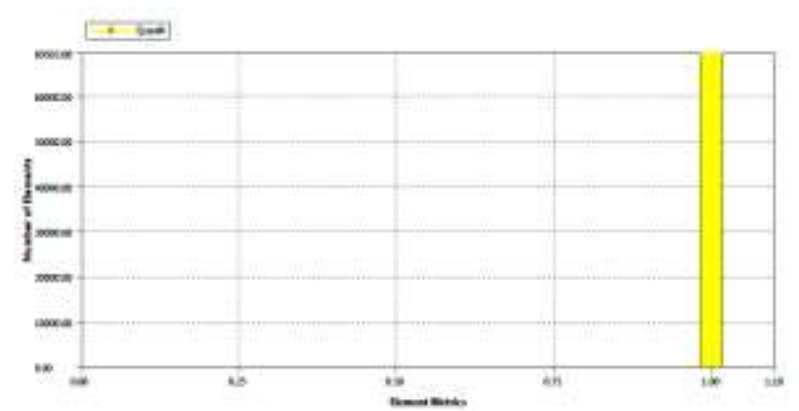

Figure 5: Orthogonal mesh quality: minimum value is 1 and maximum value is 1 and average value is 1

8 Defining Material Properties: For any kind of analysis material property are the main things which must be defined before moving further analysis. There are thousands of materials available in the ANSYS environment or library, if required materials are not available in ANSYS material directory, new material directory also can be created as per requirement. The working fluid is taken as water flowing inside the absorber tube of parabolic trough collector having density of $1000 \mathrm{~kg} / \mathrm{m} 3$, specific heat $=4182 \mathrm{~J} / \mathrm{kg}-\mathrm{k}$, thermal conductivity $=0.6 \mathrm{w} / \mathrm{m}-\mathrm{k}$ and viscosity of water liquid $=0.001003 \mathrm{~kg} / \mathrm{m}-\mathrm{s}$. The properties of the materials such as the thermal conductivity, density and heat capacity also specified in bellow table.

Figure6 : different boundaries of parabolic trough collector for design-1

\section{Boundary condition:}

1. To determine the maximum temperature inside the absorber tube of parabolic trough collector need to on energy equation.

2. Defining of material property, set fluid as water liquid and solid as copper with thermal conductivity of $0.6 \mathrm{~W} / \mathrm{m}^{-} \mathrm{K} \& 16.27 \mathrm{~W} / \mathrm{m}^{-} \mathrm{K}$.

3. Mass Flow rate of $0.014 \mathrm{~kg} / \mathrm{sec}$ was given at the inlet of the absorber tube.

4. For the outlet boundary condition the gauge pressure needs to be set as zero because the flow of water inside the absorber tube of parabolic trough collector is atmospheric.

5. Solar radiations were used on bottom walls of absorber tube.

6. The fluent solver is used for steady analysis.

\section{Computational fluid dynamics analysis for} design-1

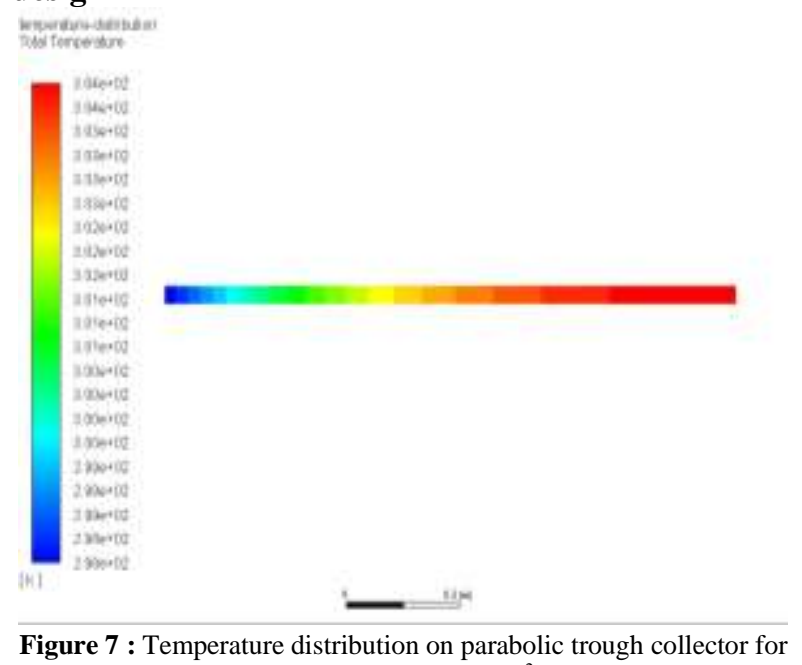

Figure 7 : Temperature distribution on parabolic trough collector for design- 1 of at $200 \mathrm{w} / \mathrm{m}^{2}$ 


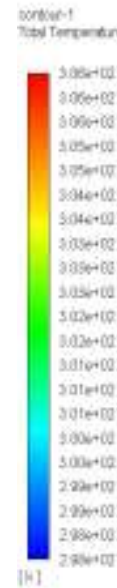

Figure 8: Temperature distribution on parabolic trough collector for design- 1 of at $400 \mathrm{w} / \mathrm{m}^{2}$

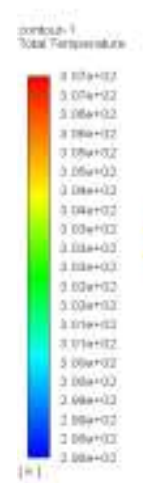

Figure 9: Temperature distribution on parabolic trough collector for design- 1 of at $600 \mathrm{w} / \mathrm{m}^{2}$

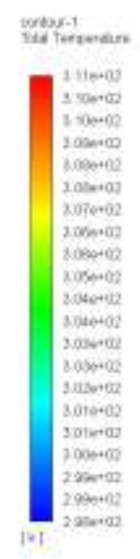

Figure 10: Temperature distribution on parabolic trough collector for design- 1 of at $800 \mathrm{w} / \mathrm{m}^{2}$

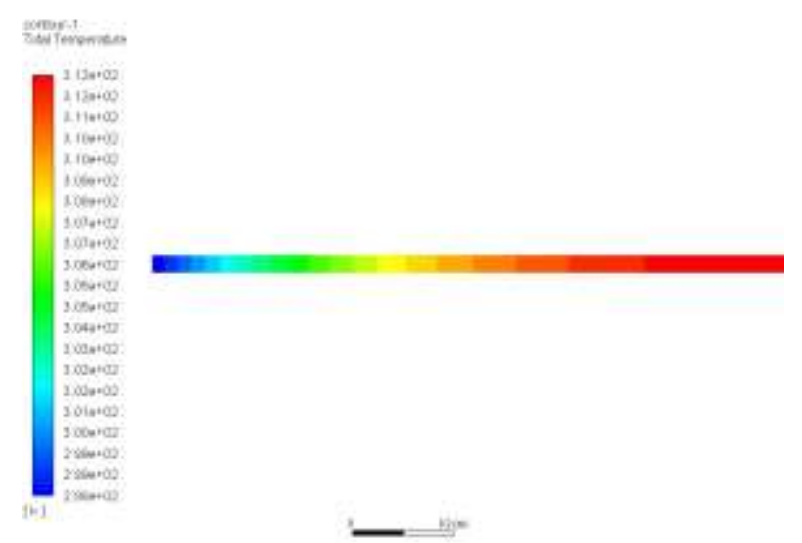

Figure 11: Temperature distribution on parabolic trough collector for design- 1 of at $900 \mathrm{w} / \mathrm{m}^{2}$

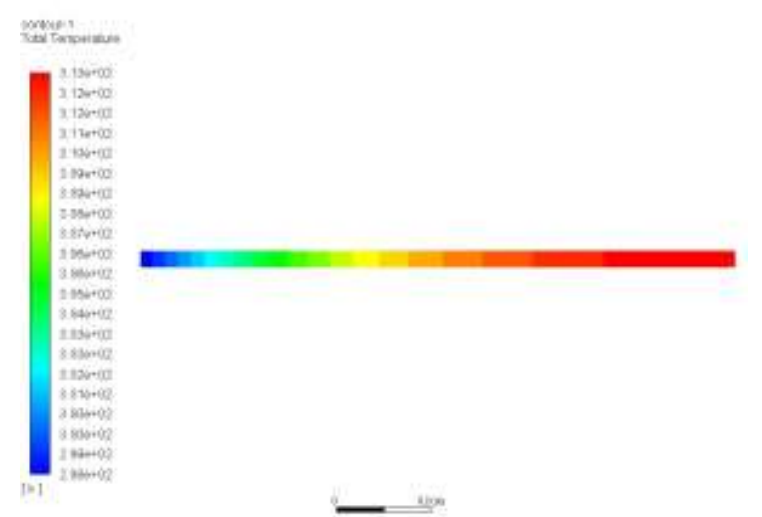

Figure 12: Temperature distribution on parabolic trough collector for design- 1 of at $1000 \mathrm{w} / \mathrm{m}^{2}$

\section{Computational fluid dynamics analysis for} design-2

1) CAD geometry:

In the present work a two dimensional CAD model of absorber tube of parabolic trough collector is created with the help of design modular of ANSYS workbench. A two dimensional view of absorber tube is shown in figure No.

3⿻上丨
Figure 13: CAD geometry of design-2 of absorber tube of parabolic trough collector

2) Meshing: After completing the $C A D$ geometry of absorber tube of parabolic trough collector is imported in ANSYS workbench for further computational fluid dynamics analysis and the next step is meshing. The size of element is set as $1 \mathrm{~mm}$ to generate mesh and the total no of nodes generated in the present work is 51051and total No. of Elements is 50000. Types of elements used are rectangular which is a rectangular in shape with four nodes on each element. 


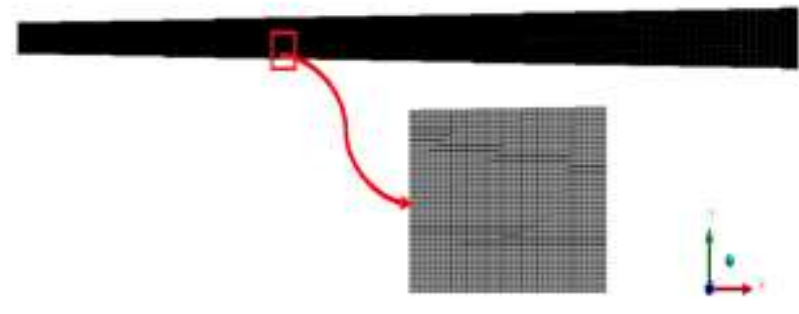

Figure 14: Meshing: total no of nodes 51051, total no. of elements 50000

3) Orthogonal mesh quality: Orthogonal quality is computed for cells using the vector from the cell centroid to each of its faces, corresponding face area vector, and the vector from the cell centroid to centroids of each of the adjacent cells. The worst cells will have an orthogonal quality closer to 0 , with the best cells closer to 1 . In the present case the minimum value is 0.999 and maximum value is 1 and average value is 0.999 , which means the mesh quality is acceptable and very good.

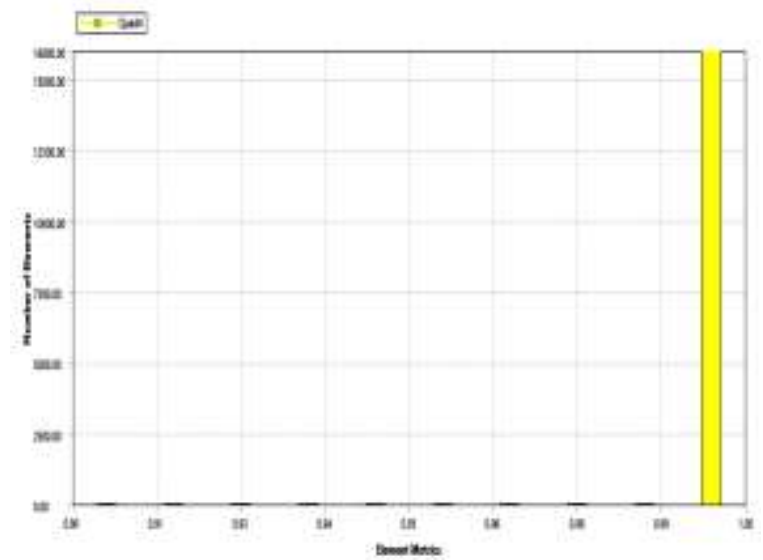

Figure 15: Orthogonal mesh quality of parabolic trough collector for design-2

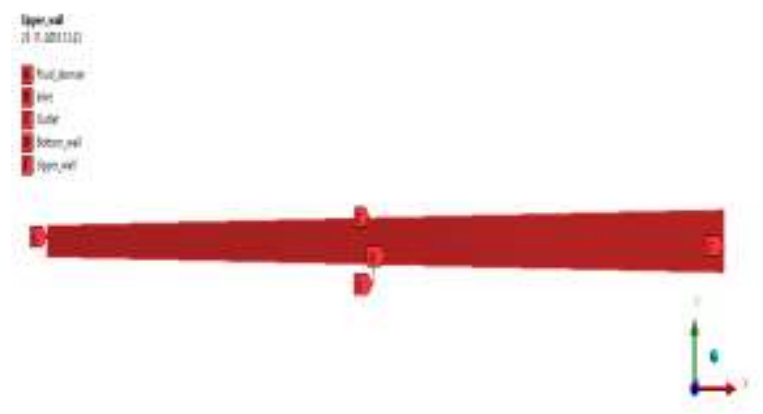

Figure16: different boundaries of parabolic trough collector for design-2

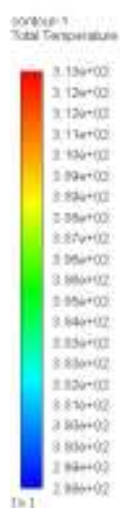

Figure 17: Temperature distribution on parabolic trough collector for design-2of at $200 \mathrm{w} / \mathrm{m} 2$

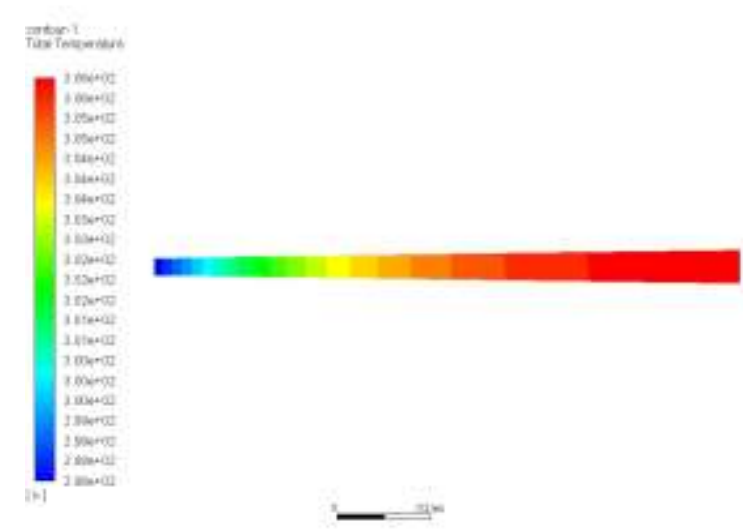

Figure 18: Temperature distribution on parabolic trough collector for design-2of at $400 \mathrm{w} / \mathrm{m}^{2}$

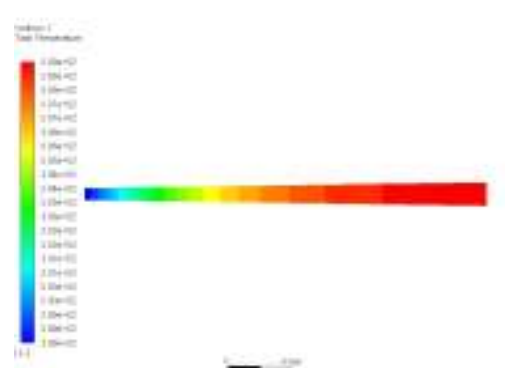

Figure 19: Temperature distribution on parabolic trough collector for design-2of at $600 \mathrm{w} / \mathrm{m}^{2}$

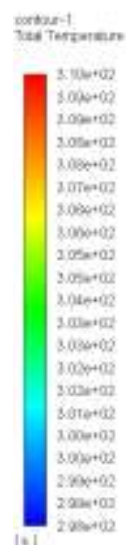

Figure 20: Temperature distribution on parabolic trough collector for design-2of at $800 \mathrm{w} / \mathrm{m}^{2}$ 


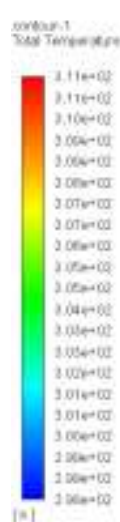

Figure 21: Temperature distribution on parabolic trough collector for design-2of at $900 \mathrm{w} / \mathrm{m}^{2}$

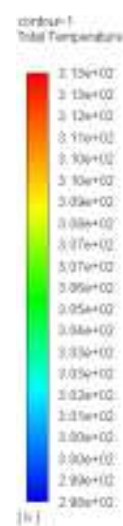

Figure 22: Temperature distribution on parabolic trough collector for design-2of at $1000 \mathrm{w} / \mathrm{m}^{2}$

12 Computational fluid dynamics analysis for

\section{design-3}

\section{1) CAD geometry:}

In the present work a two dimensional CAD model of absorber tube of parabolic trough collector is created with the help of design modular of ANSYS workbench. A two dimensional view of absorber tube is shown in figure No.

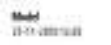

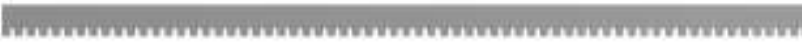

Figure 23: CAD geometry of design-2 of absorber tube of parabolic trough collector

2) Meshing: After completing the CAD geometry of absorber tube of parabolic trough collector is imported in ANSYS workbench for further computational fluid dynamics analysis and the next step is meshing. The size of element is set as $1 \mathrm{~mm}$ to generate mesh and the total no of nodes generated in the present work is 29183 and total No. of Elements is 27690. Types of elements used are rectangular which is a rectangular in shape with four nodes on each element.

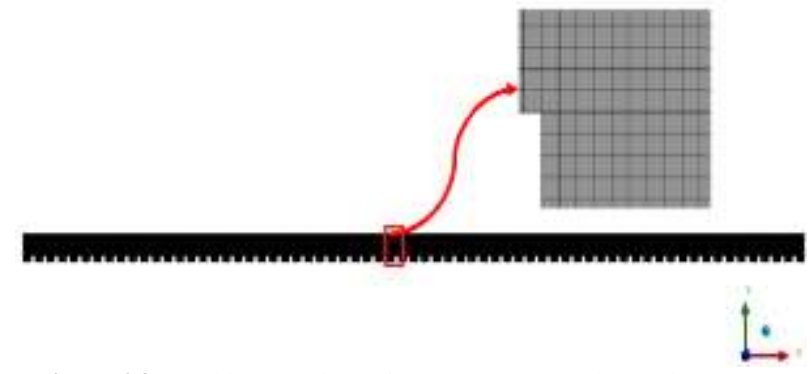

Figure 24: Meshing: total no of nodes 29183, total no. of elements 27690

3) Orthogonal mesh quality: Orthogonal quality is computed for cells using the vector from the cell centroid to each of its faces, corresponding face area vector, and the vector from the cell centroid to centroids of each of the adjacent cells. The worst cells will have an orthogonal quality closer to 0 , with the best cells closer to 1 . In the present case the minimum value is 1 and maximum value is 1 and average value is 1 , which means the mesh quality is acceptable and very good.

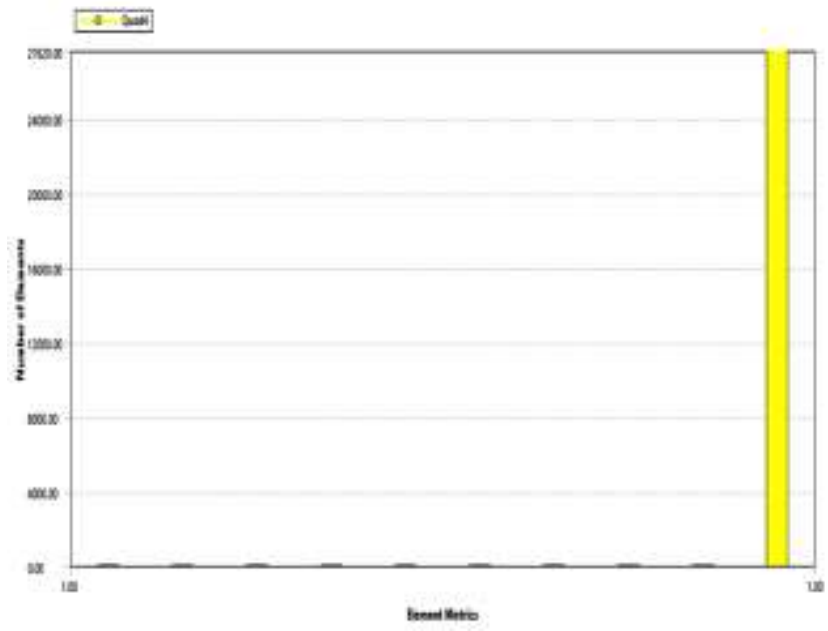

Figure 25: Orthogonal mesh quality of parabolic trough collector for design-3

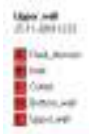

eำ

Figure26: different boundaries of parabolic trough collector for design-3 

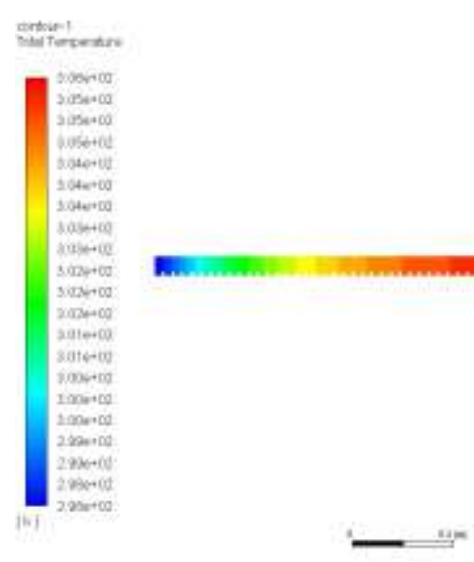

Figure 27 : Temperature distribution on parabolic trough collector for design -3 of at $200 \mathrm{w} / \mathrm{m}^{2}$

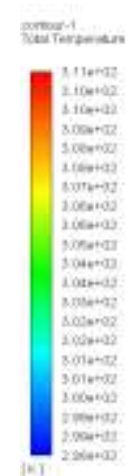

Figure 28: Temperature distribution on parabolic trough collector for design-3 of at $400 \mathrm{w} / \mathrm{m}^{2}$

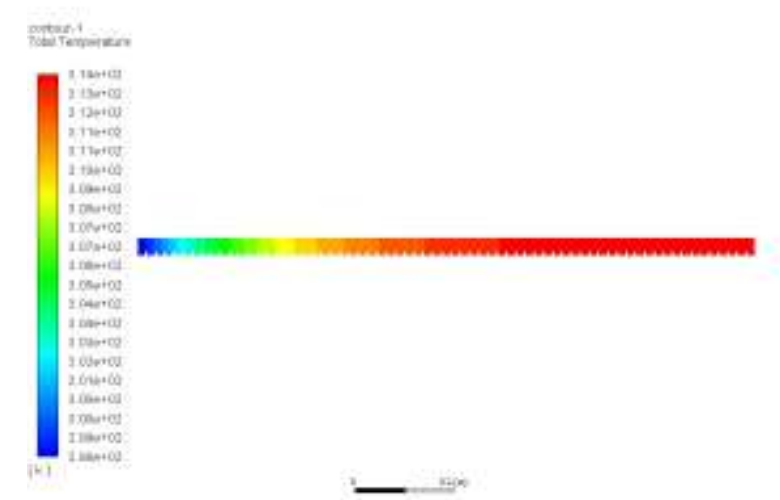

Figure 29: Temperature distribution on parabolic trough collector for design- 3 of at $600 \mathrm{w} / \mathrm{m}^{2}$

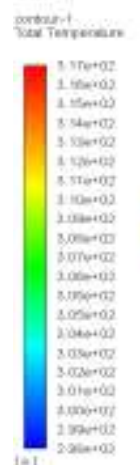

Figure 30: Temperature distribution on parabolic trough collector for design-3 of at $800 \mathrm{w} / \mathrm{m}^{2}$

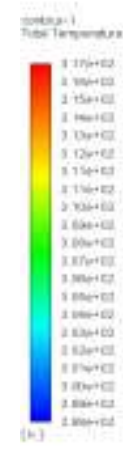

Figure 31: Temperature distribution on parabolic trough collector for design- 3 of at $900 \mathrm{w} / \mathrm{m}^{2}$

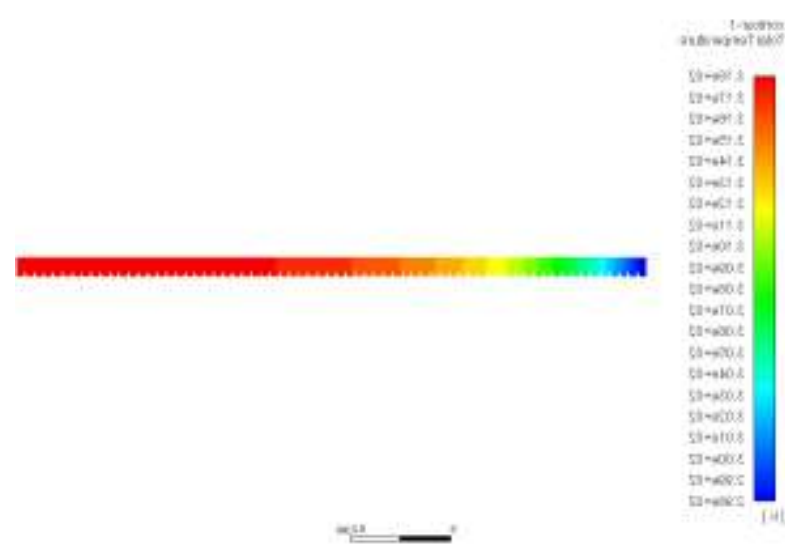

Figure 32: Temperature distribution on parabolic trough collector for design- 3 of at $1000 \mathrm{w} / \mathrm{m}^{2}$

\section{Computational fluid dynamics analysis for} design-4

1) CAD geometry:

In the present work a two dimensional CAD model of absorber tube of parabolic trough collector is created with the help of design modular of ANSYS workbench. A two dimensional view of absorber tube is shown in figure No.

simention 
are rectangular which is a rectangular in shape with four nodes on each element.

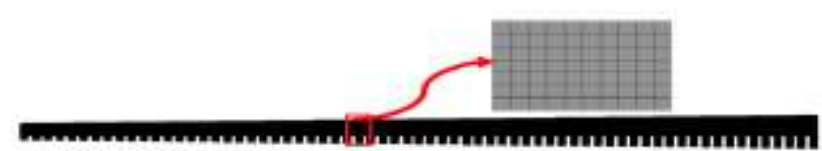

Figure 34: Meshing: total no of nodes 43158, total no. of elements 41141

3) Orthogonal mesh quality: Orthogonal quality is computed for cells using the vector from the cell centroid to each of its faces, corresponding face area vector, and the vector from the cell centroid to centroids of each of the adjacent cells. The worst cells will have an orthogonal quality closer to 0 , with the best cells closer to 1 . In the present case the minimum value is 0.7758 and maximum value is 1 and average value is 0.998 , which means the mesh quality is acceptable and very good.

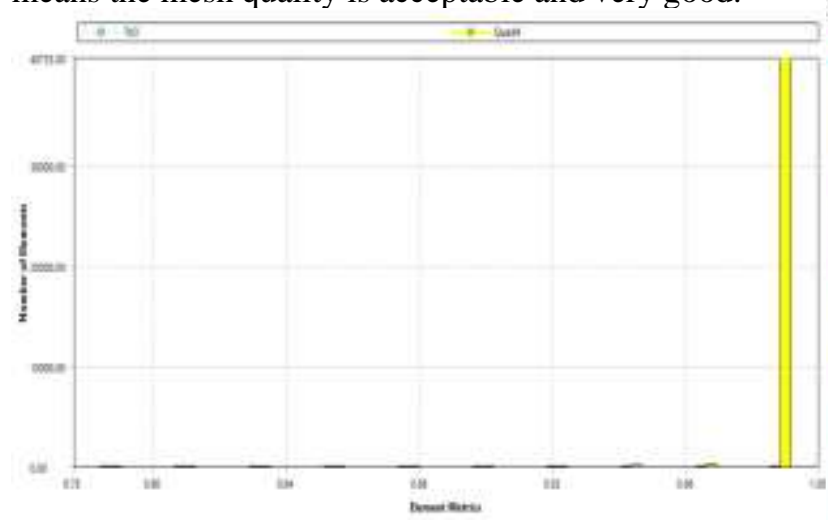

Figure 35: Orthogonal mesh quality of parabolic trough collector for design-4

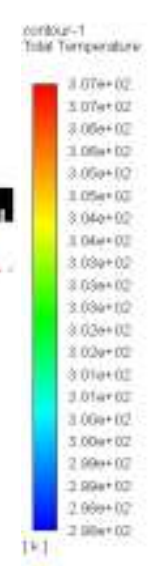

Figure 37: Temperature distribution on parabolic trough collector for design- 4 of at $200 \mathrm{w} / \mathrm{m}^{2}$

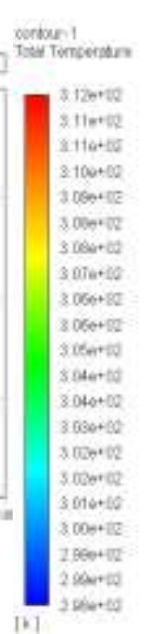

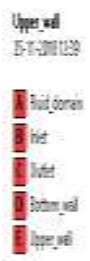

Figure 38 : Temperature distribution on parabolic trough collector for design- 4 of at $400 \mathrm{w} / \mathrm{m}^{2}$
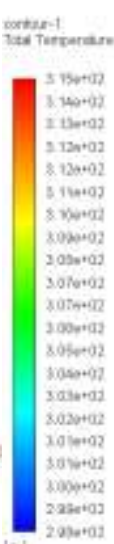

Figure 39: Temperature distribution on parabolic trough collector for design- 4 of at $600 \mathrm{w} / \mathrm{m}^{2}$ 

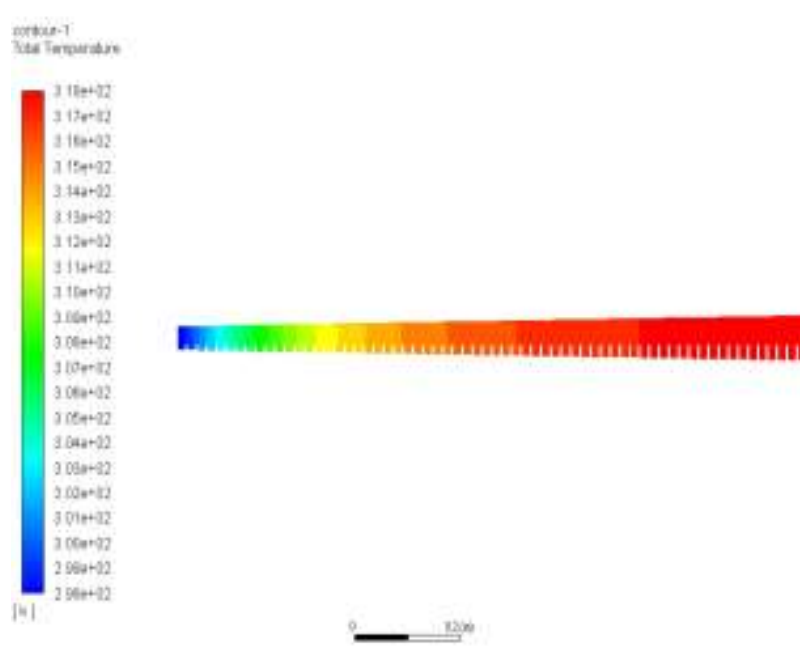

Figure 40 : Temperature distribution on parabolic trough collector for design- 4 of at $800 \mathrm{w} / \mathrm{m}^{2}$

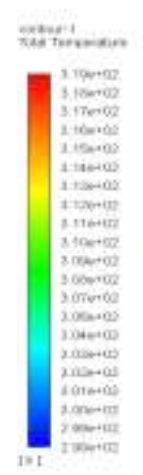

Figure 41: Temperature distribution on parabolic trough collector for design- 4 of at $900 \mathrm{w} / \mathrm{m}^{2}$

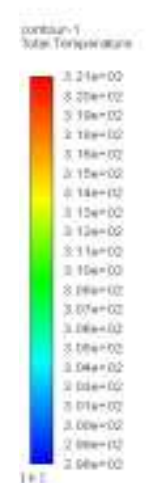

Figure 42: Temperature distribution on parabolic trough collector for design- 4 of at $1000 \mathrm{w} / \mathrm{m}^{2}$

\section{RESULT ANALYSIS}

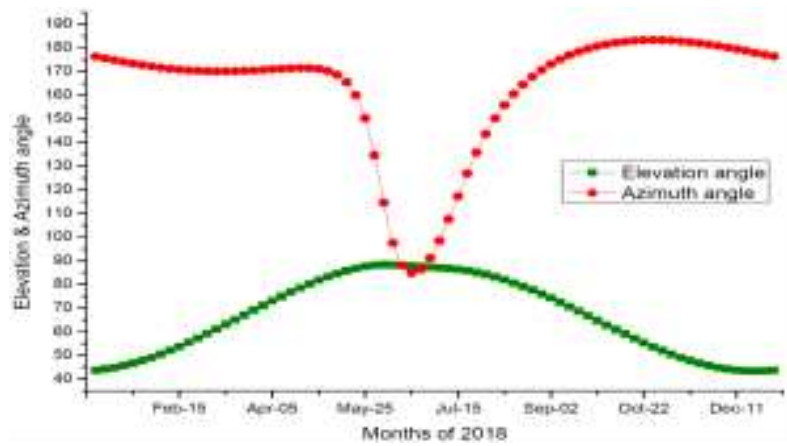

Figure 43: Elevation \& Azimuth angle for Bhopal location

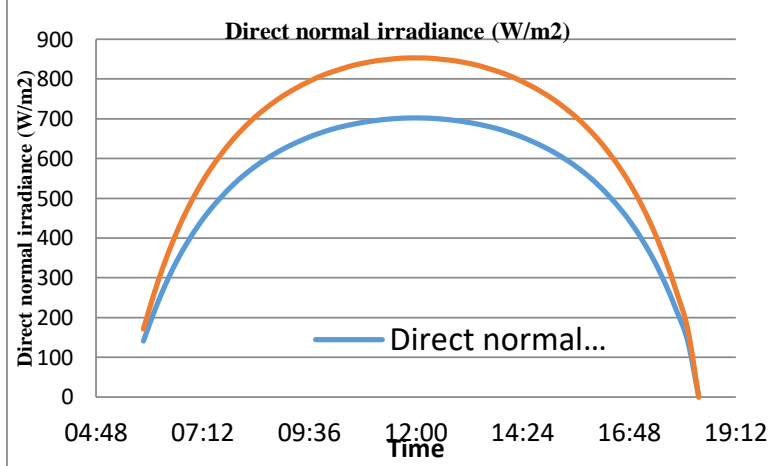

Figure 44: Direct normal irradiance (W/m2) for May 2018

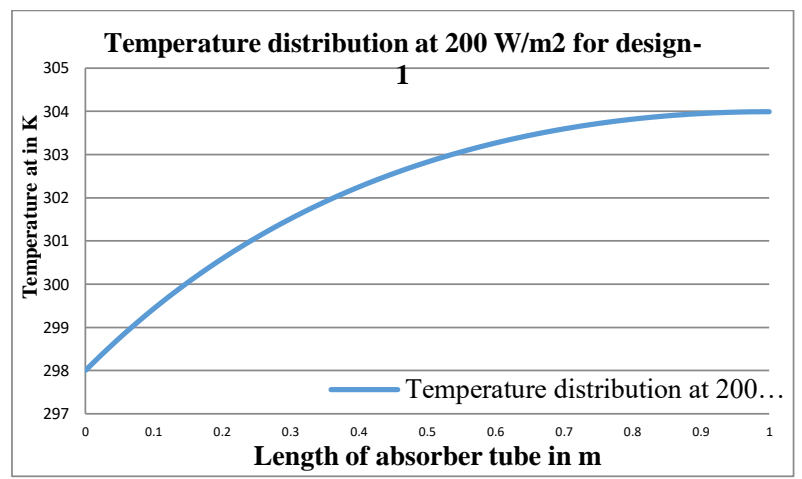

Figure 45: Temperature distribution at $200 \mathrm{~W} / \mathrm{m} 2$ for design-1

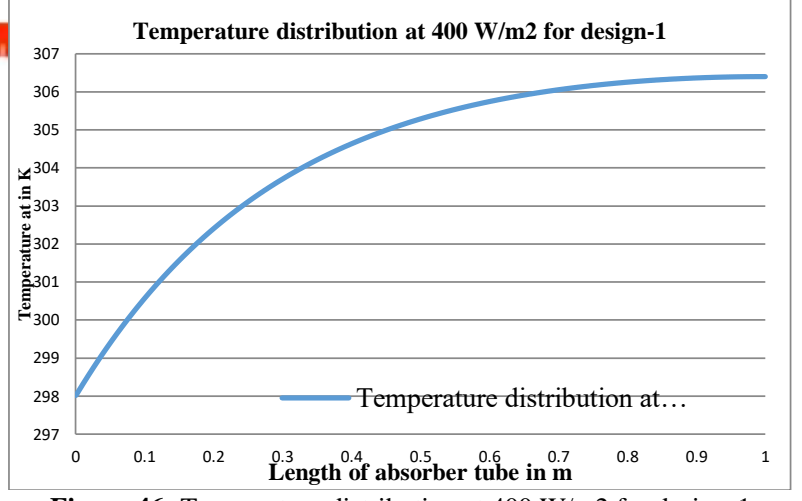

Figure 46: Temperature distribution at $400 \mathrm{~W} / \mathrm{m} 2$ for design-1 


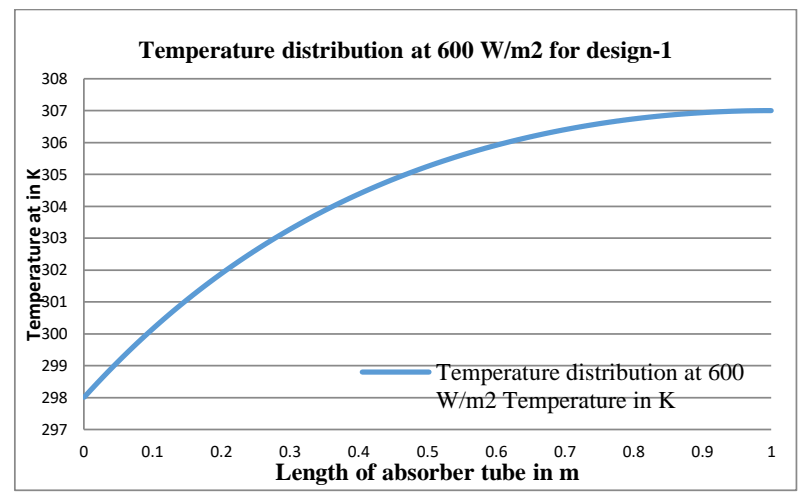

Figure 47: Temperature distribution at $600 \mathrm{~W} / \mathrm{m} 2$ for design-1

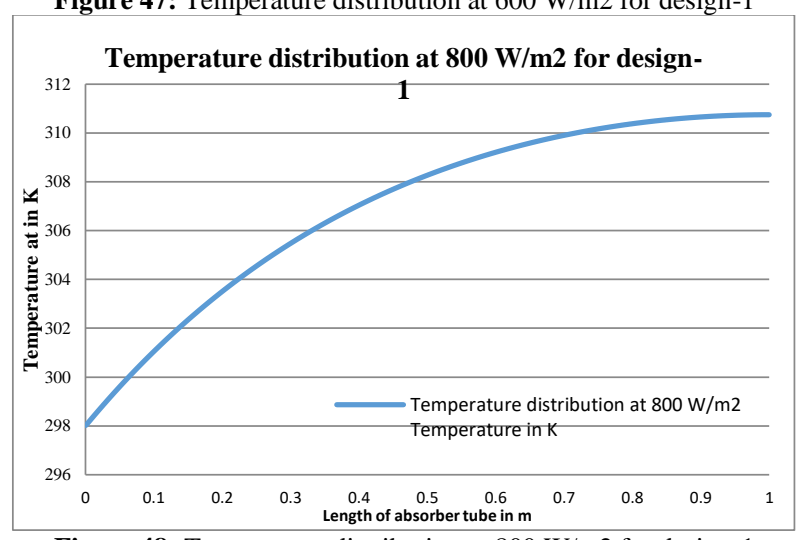

Figure 48: Temperature distribution at $800 \mathrm{~W} / \mathrm{m} 2$ for design-1

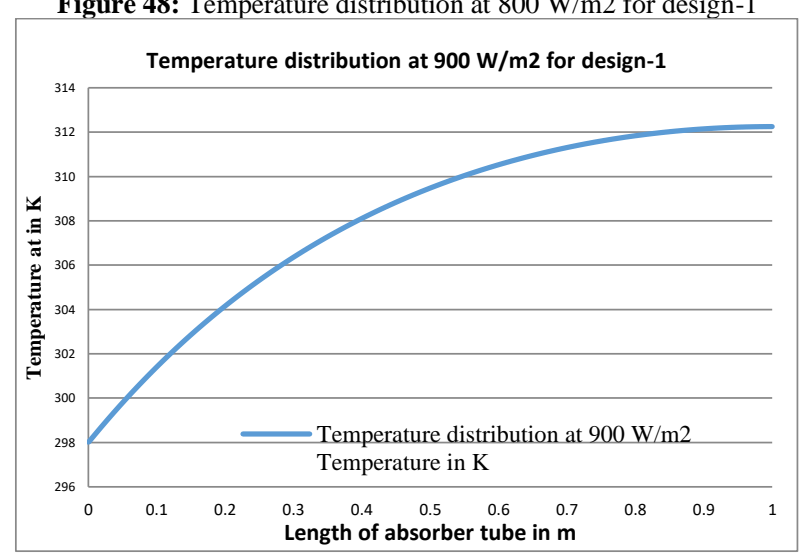

Figure 49: Temperature distribution at $900 \mathrm{~W} / \mathrm{m} 2$ for design-1

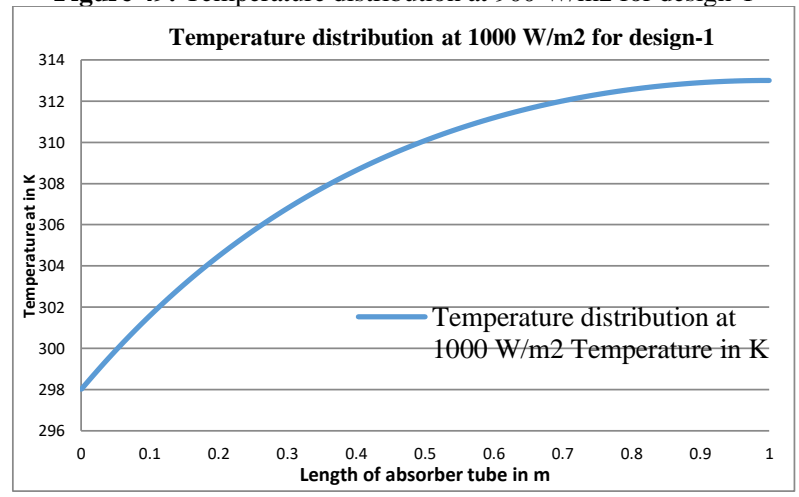

Figure 50: Temperature distribution at $1000 \mathrm{~W} / \mathrm{m} 2$ for design-1

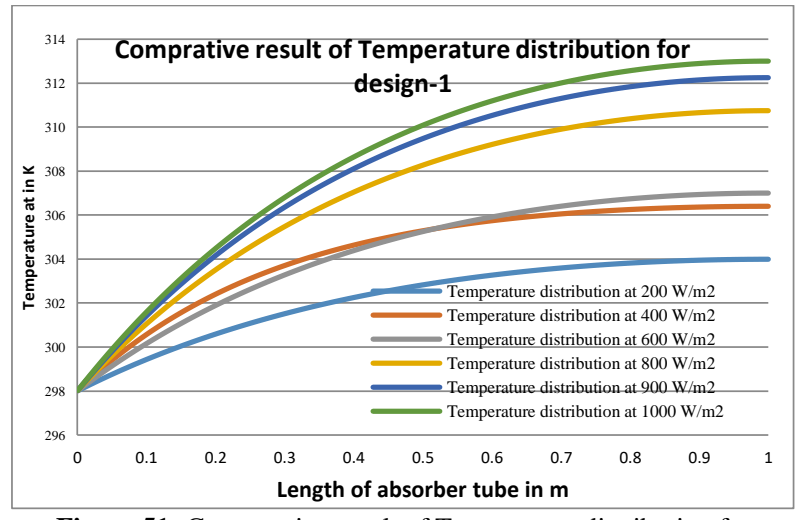

Figure 51: Comparative result of Temperature distribution for design-1

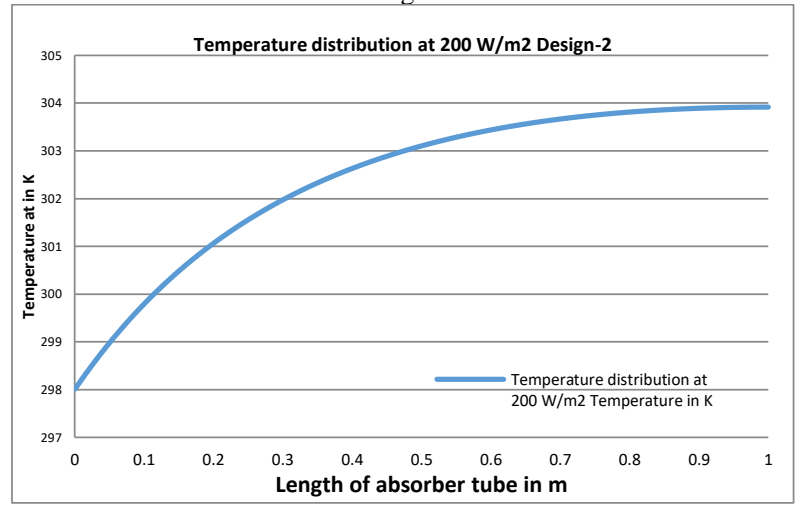

Figure 52: Temperature distribution at $200 \mathrm{~W} / \mathrm{m} 2$ for design-2

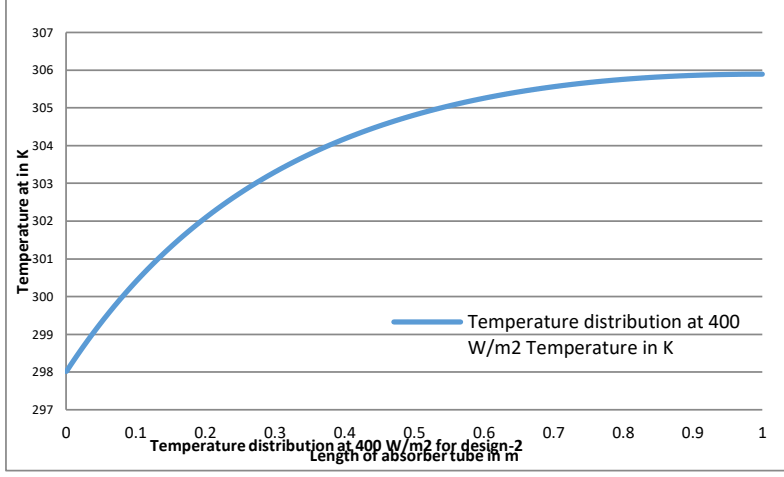

Figure 53: Temperature distribution at $400 \mathrm{~W} / \mathrm{m} 2$ for design-2

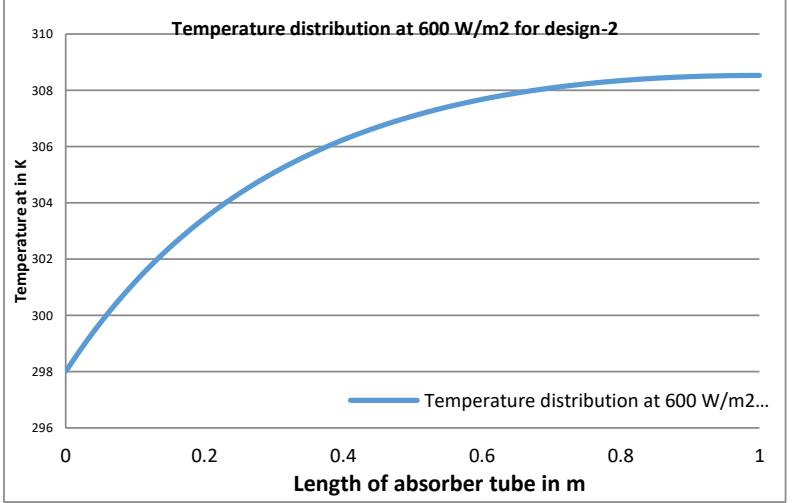

Figure 54: Temperature distribution at $600 \mathrm{~W} / \mathrm{m} 2$ for design-2 


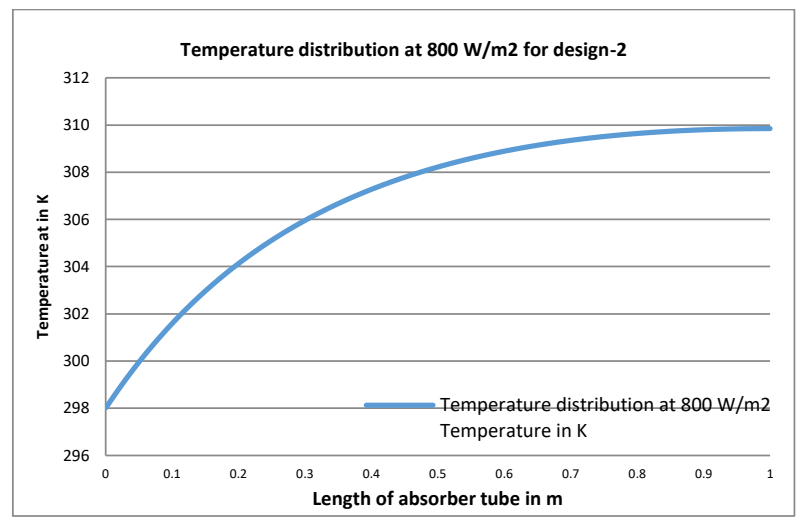

Figure55 : Temperature distribution at $800 \mathrm{~W} / \mathrm{m} 2$ for design-2

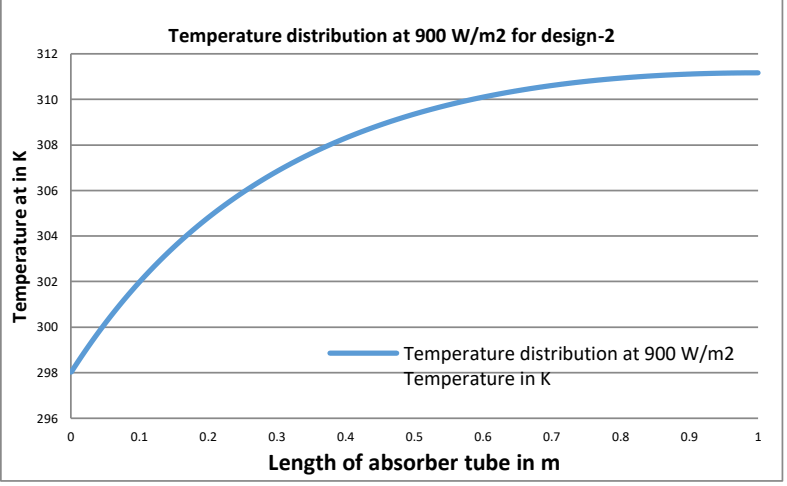

Figure 56 : Temperature distribution at $900 \mathrm{~W} / \mathrm{m} 2$ for design- 2

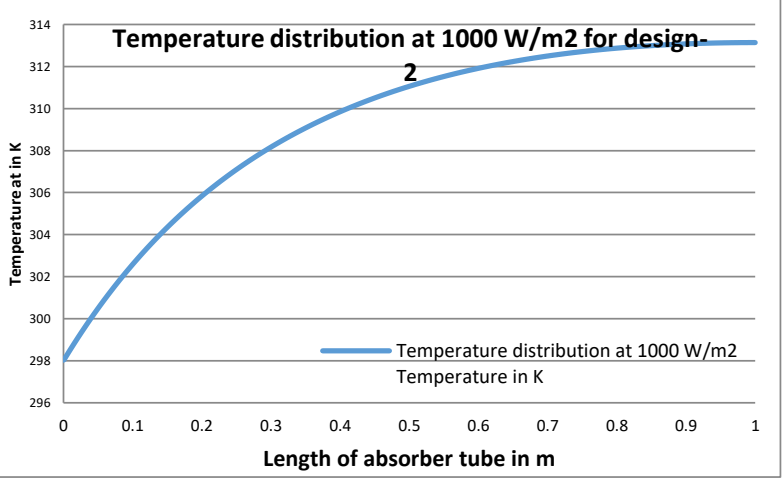

Figure 57: Temperature distribution at $1000 \mathrm{~W} / \mathrm{m} 2$ for design-2 Comprative result of Temperature distribution for design-2

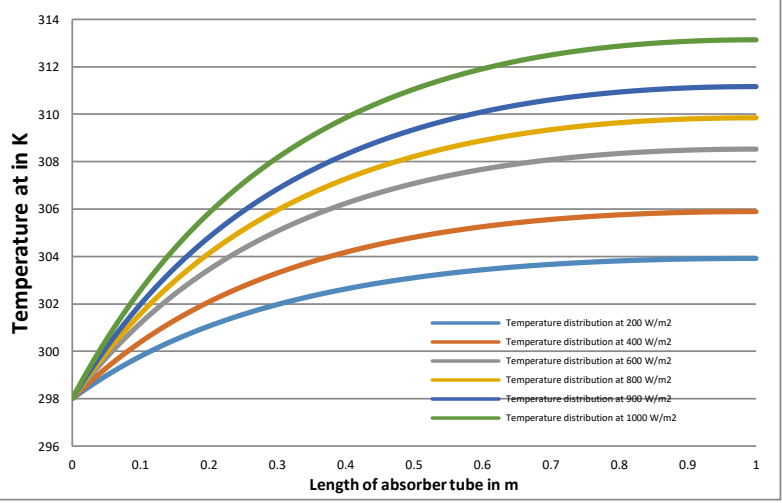

Figure 58: Comparative result of Temperature distribution for design-2

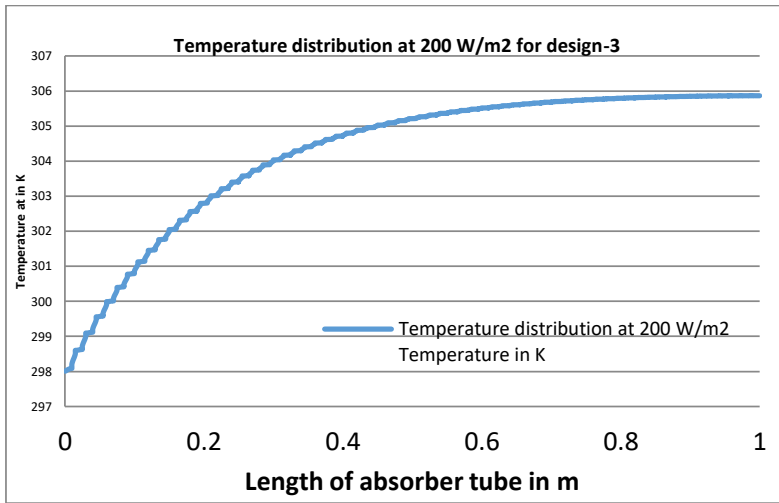

Figure 59: Temperature distribution at $200 \mathrm{~W} / \mathrm{m} 2$ for design-3

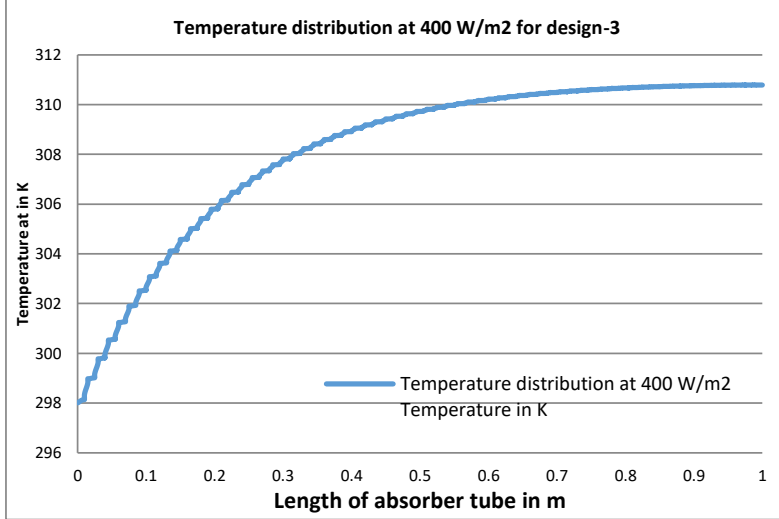

Figure 60: Temperature distribution at $400 \mathrm{~W} / \mathrm{m} 2$ for design-3

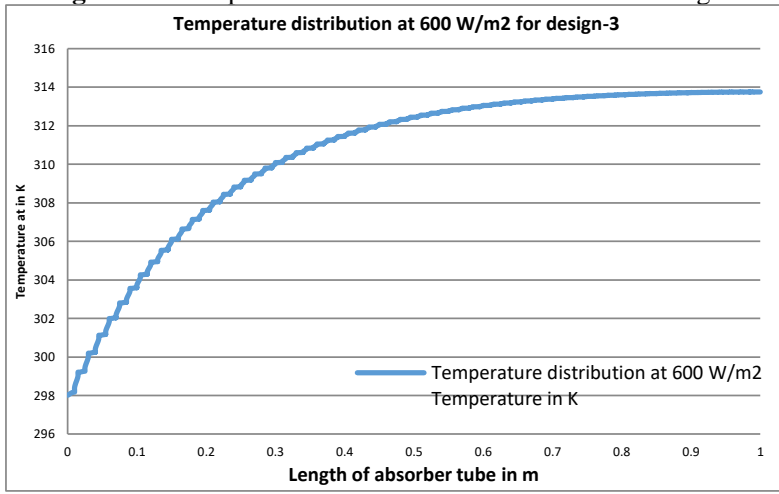

Figure 61: Temperature distribution at $600 \mathrm{~W} / \mathrm{m} 2$ for design-3

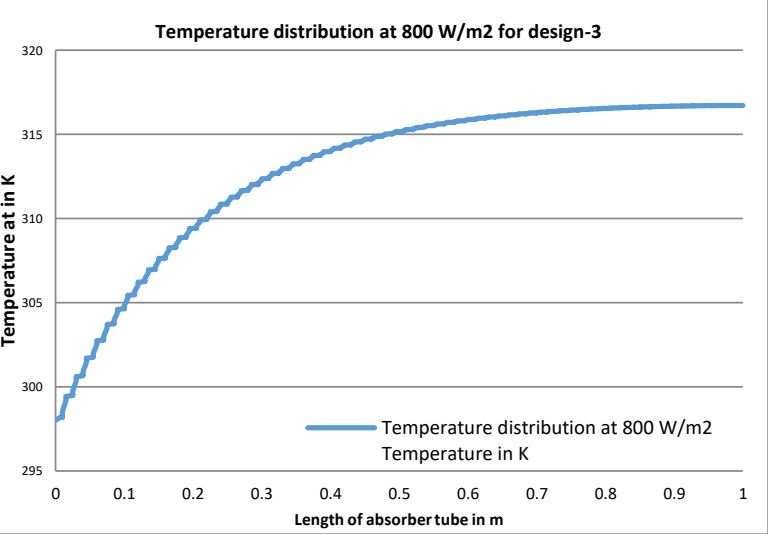

Figure 62: Temperature distribution at $800 \mathrm{~W} / \mathrm{m} 2$ for design-3 


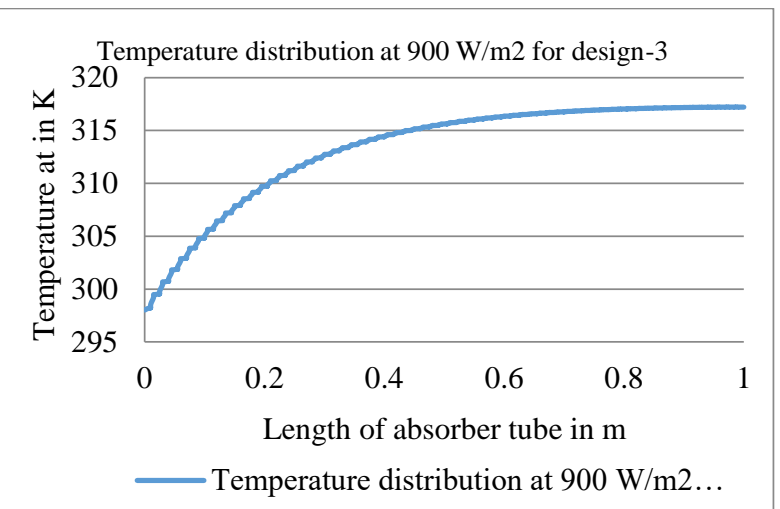

Figure 63: Temperature distribution at $900 \mathrm{~W} / \mathrm{m} 2$ for design-3

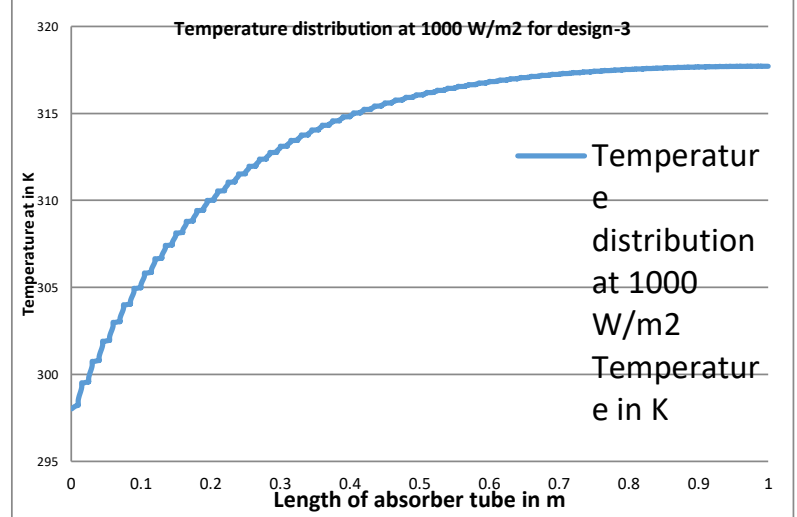

Figure 64: Temperature distribution at $1000 \mathrm{~W} / \mathrm{m} 2$ for design-3

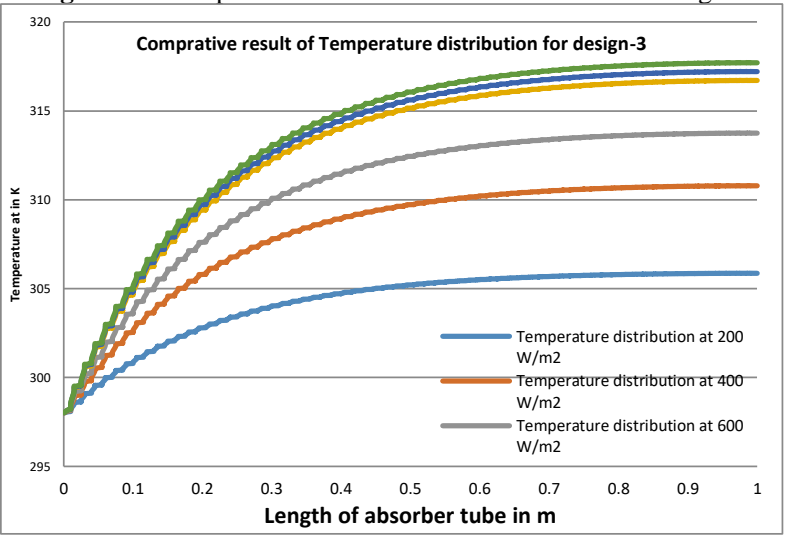

Figure 65: Comparative result of Temperature distribution for design-3

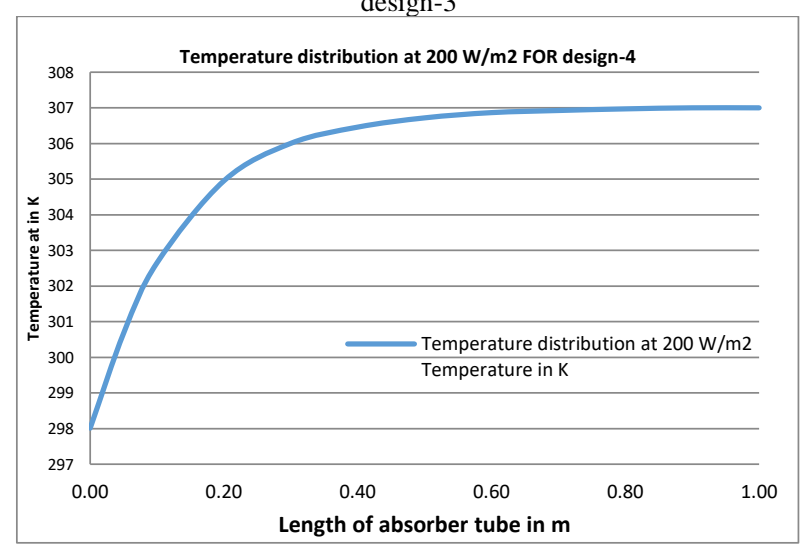

Figure 66: Temperature distribution at $200 \mathrm{~W} / \mathrm{m} 2$ for design- 4

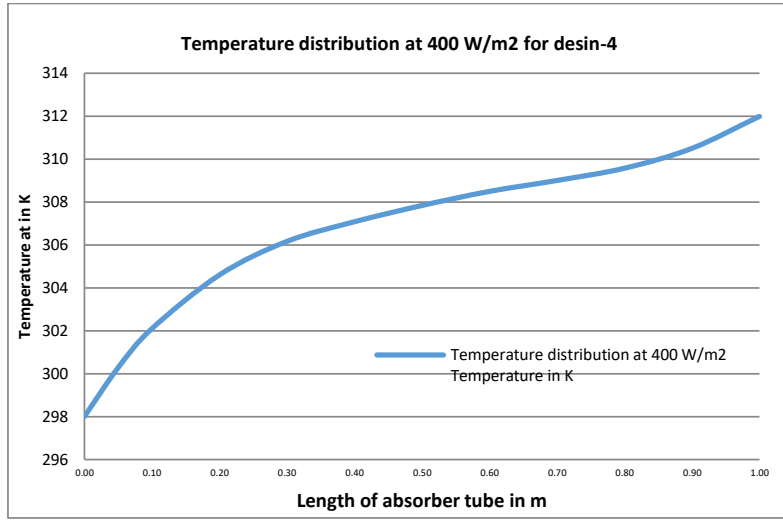

Figure 67: Temperature distribution at $400 \mathrm{~W} / \mathrm{m} 2$ for design- 4

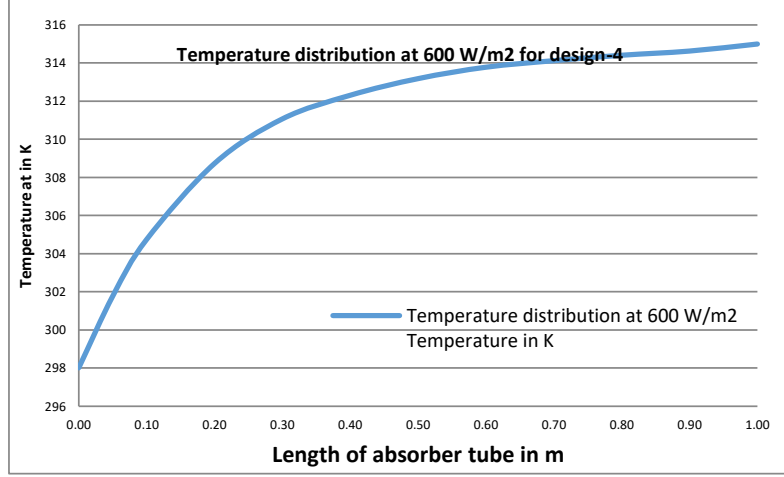

Figure 68: Temperature distribution at $600 \mathrm{~W} / \mathrm{m} 2$ for design- 4

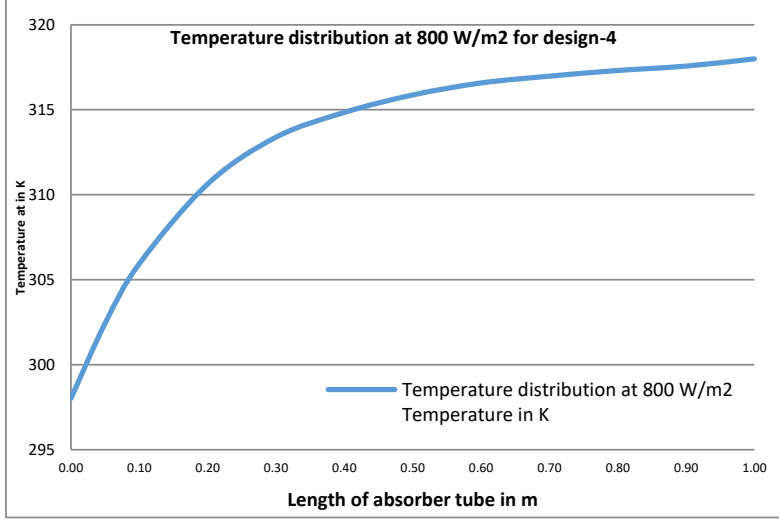

Figure 69: Temperature distribution at $800 \mathrm{~W} / \mathrm{m} 2$ for design- 4

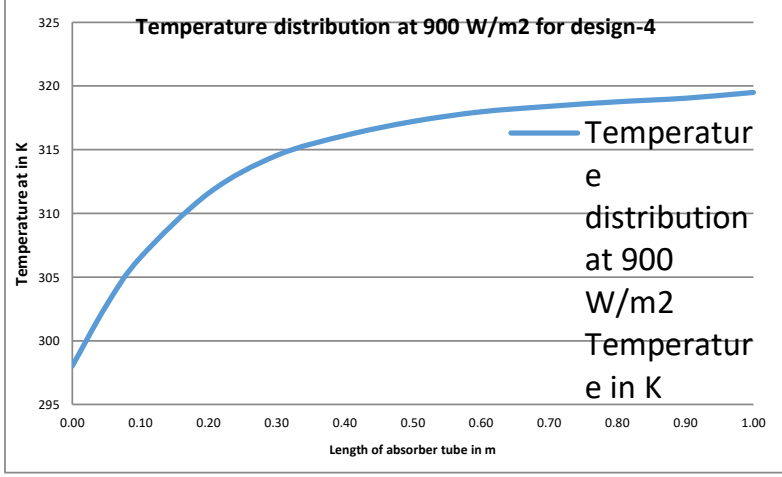

Figure 70: Temperature distribution at $900 \mathrm{~W} / \mathrm{m} 2$ for design- 4 


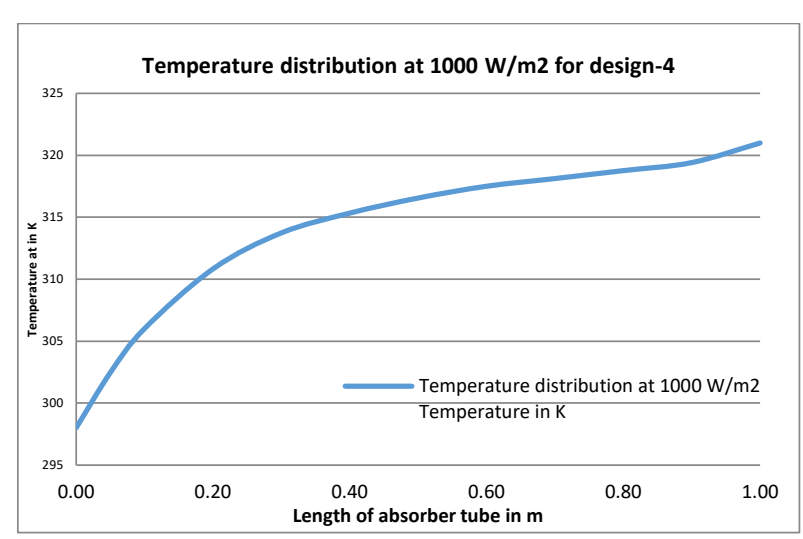

Figure 71: Temperature distribution at $1000 \mathrm{~W} / \mathrm{m} 2$ for design-4

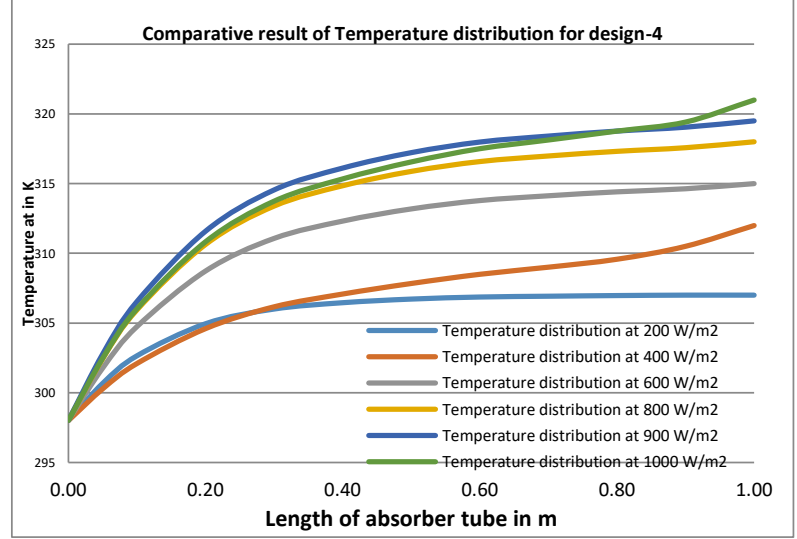

Figure 72: Comparative result of Temperature distribution for design-4

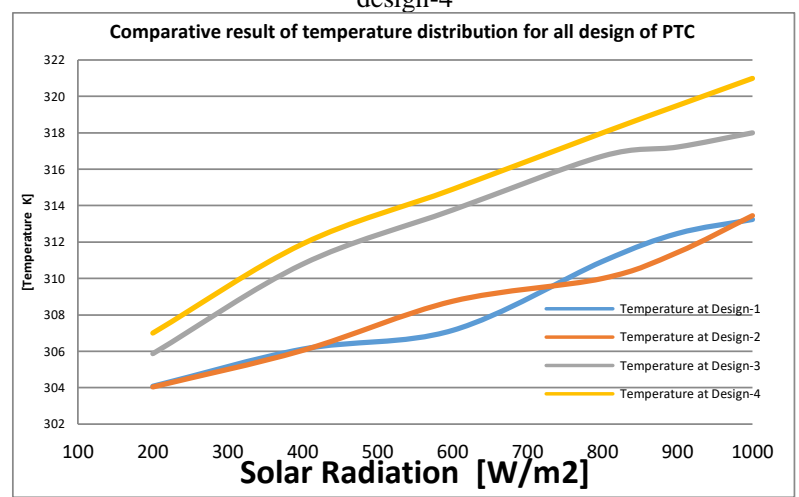

Figure 73: Comparative result of temperature distribution for all design of PTC

\section{CONCLUSION AND FUTURE WORK}

In the present work computational fluid dynamics analysis have been performed at four different designs of the absorber tube of parabolic trough collector for Bhopal location to get better heating performance and temperature distribution over the absorber tube and compared the results. There are following conclusive points drawn from this work.

1. After performing computational fluid dynamics analysis for an absorber tube of parabolic trough collector of designs from base paper at different solar radiation $\left(200 \mathrm{w} / \mathrm{m}^{2}, 400 \mathrm{w} / \mathrm{m}^{2}, 600 \mathrm{w} / \mathrm{m}^{2}, 800 \mathrm{w} / \mathrm{m}^{2}, 900\right.$ $\mathrm{w} / \mathrm{m}^{2}$ and $1000 \mathrm{w} / \mathrm{m}^{2}$ ) the temperature at outlet are $304.08 \mathrm{~K}, 306.12 \mathrm{~K}, 307.15 \mathrm{~K}, 310.94 \mathrm{~K}, 312.47 \mathrm{~K}$ and $313.24 \mathrm{~K}$.
2. After performing computational fluid dynamics analysis for design-2 of absorber tube of parabolic trough collector at different solar radiation $\left(200 \mathrm{w} / \mathrm{m}^{2}, 400\right.$ $\mathrm{w} / \mathrm{m}^{2}, 600 \mathrm{w} / \mathrm{m}^{2}, 800 \mathrm{w} / \mathrm{m}^{2}, 900 \mathrm{w} / \mathrm{m}^{2}$ and $1000 \mathrm{w} / \mathrm{m}^{2}$ ) the temperature at outlet are $304.04 \mathrm{~K}, 306.05 \mathrm{~K}, 308.75 \mathrm{~K}$, $310 \mathrm{~K}, 311.43 \mathrm{~K}$ and $313.45 \mathrm{~K}$.

3. After performing computational fluid dynamics analysis for design-3 of absorber tube of parabolic trough collector at different solar radiation $\left(200 \mathrm{w} / \mathrm{m}^{2}, 400\right.$ $\mathrm{w} / \mathrm{m}^{2}, 600 \mathrm{w} / \mathrm{m}^{2}, 800 \mathrm{w} / \mathrm{m}^{2}, 900 \mathrm{w} / \mathrm{m}^{2}$ and $\left.1000 \mathrm{w} / \mathrm{m}^{2}\right)$ the temperature at outlet are $305.87 \mathrm{~K}, 310.79 \mathrm{~K}, 313.76 \mathrm{~K}$, $316.72 \mathrm{~K}, 317.22 \mathrm{~K}$ and $318 \mathrm{~K}$.

4. After performing computational fluid dynamics analysis for design-4 of absorber tube of parabolic trough collector at different solar radiation $\left(200 \mathrm{w} / \mathrm{m}^{2}, 400\right.$ $\mathrm{w} / \mathrm{m}^{2}, 600 \mathrm{w} / \mathrm{m}^{2}, 800 \mathrm{w} / \mathrm{m}^{2}, 900 \mathrm{w} / \mathrm{m}^{2}$ and $1000 \mathrm{w} / \mathrm{m}^{2}$ ) the temperature at outlet are $307 \mathrm{~K}, 311.9 \mathrm{~K}, 314.9 \mathrm{~K}, 318 \mathrm{~K}$, $319.5 \mathrm{~K}$ and $320.99 \mathrm{~K}$.

It has been observe that in first design of absorber tube of parabolic trough collector having maximum temperature at solar radiation of $1000 \mathrm{w} / \mathrm{m}^{2}$ at outlet has been recorded $313.24 \mathrm{~K}$ while from design-2, design-3 and design- 4 the maximum temperature at outlet are $313.45 \mathrm{~K}, 318 \mathrm{~K}$ and $320.99 \mathrm{~K}$ respectively. So that it is recommended that the design- 4 of the absorber tube of parabolic trough collector gives the higher temperature.

\section{REFERENCES}

[1] Evangelos Bellos, Christos Tzivanidis \& Dimitrios Tsimpoukis "Optimum number of internal fins in parabolic trough collectors" Applied Thermal Engineering 137 (2018) 669-677.

[2] Hamed Hoseinzadeh, Alibakhsh Kasaeian \& Mohammad Behshad Shafii "Geometric optimization of parabolic trough solar collector based on the local concentration ratio using the Monte Carlo method" Energy Conversion and Management 175 (2018) 278-287.

[3] Salamanca S, Merchán P, Adán A \& Pérez E “An appraisal of the geometry and energy efficiency of parabolic trough collectors with laser scanners and image processing" Renewable Energy (2018), doi: https://doi.org/10.1016/j.renene.2018.11.014.

[4] Adriano Desideri at el. "Steady-state and dynamic validation of a parabolic trough collector model using the Thermo-Cycle Modelica library" Solar Energy 174 (2018) 866-877.

[5] Ali Jaber Abdulhamed at el. "Review of solar parabolictrough collector geometrical and thermal analyses, performance, and applications" Renewable and Sustainable Energy Reviews 91 (2018) 822-831.

[6] Benjamin Ahlgren at el. "A simplified model for linear correlation between annual yield and DNI for parabolic trough collectors" Energy Conversion and Management 174 (2018) 295-308.

[7] Asma Aichouba at el. "Influence of the displacement of solar receiver tubes on the performance of a parabolictrough collector" Energy (2018), doi: 10.1016/j.energy.2018.06.148.

[8] Evangelos Bellos, Christos Tzivanidis \& Dimitrios Tsimpoukis "Enhancing the performance of parabolic trough collectors using nanofluids and turbulators" Renewable and Sustainable Energy Reviews 91 (2018) 358-375. 